Journal of Southeast Asian Studies, 48(3), pp 349-371 October 2017.

(c) The National University of Singapore, 2017 doi:10.1017/S0022463417000534

\title{
Seas, oceans and cosmologies in Southeast Asia
}

\author{
Barbara Watson Andaya
}

This article discusses the changing spirit world of maritime communities in Southeast Asia by differentiating 'oceans' from 'seas' and by linking historical evidence to modern anthropological studies. Since the lives of seagoing peoples are fraught with unpredictability, propitiation of local sea spirits was a traditional means of ensuring good fortune and protection. As long-distance voyages expanded in the early modern period, the global reach of the world religions, extending beyond familiar seas into the more extensive ocean environment, held out particular appeal. Not only were the gods, deities and saints attached to larger religious systems themselves ocean travellers; in contrast to the unpredictability of indigenous spirits, they were always amenable to requests for help, even when the suppliant was far from home waters. At the same time, as world religions were incorporated into indigenous cosmologies, maritime peoples gained greater agency in negotiating relationships with the local spirits that still wield power in Southeast Asian seas.

More than a hundred years ago the first female president of the American Geographical Association, Ellen Churchill Semple (1863-1932), published Influences of geographic environment, now considered a pioneering work in the study of human-environmental interaction. ${ }^{1}$ In her discussion of 'coast peoples' she argued that littoral societies world-wide occupy a 'peculiar habitat', where estuaries and enclosed seas operated as an 'elementary school' for honing navigational skills before the 'larger maritime spirit' moved on to the open ocean. ${ }^{2}$ Although the oncepopular theories of environmental determinism that Semple espoused have long since been discarded, other aspects of her writings have resurfaced in recent scholarship. In particular, scholars have stressed a distinction between 'oceans', or large expanses of

Barbara Watson Andaya is Professor of Asian Studies at the University of Hawai' i. Correspondence in connection with this article should be addressed to: bandaya@hawaii.edu. She is currently working on religious interactions in early modern Southeast Asia. She would like to thank the organisers of the conference for which this article was originally prepared: Professor Kim Byong-joon, Dean, College of Humanities and the faculty of the Department of Asian Languages and Literature, Seoul National University, and especially Dr Koh Keng We. She is also grateful to suggestions from the anonymous reader, which helped improve the article.

1 Ellen Churchill Semple, Influences of geographic environment on the basis of Ratzel's system of anthropo-geography (New York: Henry Holt, 1911); Martin W. Lewis, 'Ellen Churchill Semple and paths not taken', Geocurrents, 11 Feb. 2011, http://geocurrents.info/geographical-thought/ellen-churchill-semple-and-paths-not-taken (last accessed 29 Oct. 2016).

2 Semple, Influences of geographic environment, pp. 244, 271, 294, 302. 
open salt water, and 'seas', distinguished not merely by their smaller size and proximity to land, but by the 'local meanings' with which they are infused. ${ }^{3}$

While Semple is rarely referenced, several contemporary studies have reiterated her view that littoral communities have more in common with each other than with inland societies in the same country and that these similarities provide a framework for the broader notion of 'maritime history'. ${ }^{4}$ To date, comparative work on coastal societies has tended to focus on parallels in economies, lifestyles, navigational skills, labour specialisation and gender relations. However, these studies have also shown that the lives of peoples reliant on the sea are fraught with unpredictability, and that belief in the efficacy of spirit propitiation is a common means of ensuring both good fortune and protection.

In this context, Southeast Asia, a region linked by internal seas but long connected to the Indian and Pacific Oceans, provides a unique laboratory in which to consider human responses to different maritime environments. The 'local meanings' tied to coastal areas and the surrounding seascape were underpinned by a widespread recognition that supernatural forces inhabited shorelines, reefs, rocky outcroppings, cliffs and promontories, and that they had a special relationship with marine creatures. Yet though these beings inspired and expected great respect among seafarers, their reach was limited. Even the formidable Ratu Kidul, whom the Javanese saw as reigning over the Southern Sea, had no jurisdiction in distant zones like the coasts of China or the Bay of Bengal. In southern Vietnam the Palace Damsel was once a goddess of fishing, but the many devotees who wish to offer thanks for their escape by boat after the Communist victory in 1975 must return from overseas to her shrine in Long Hai. ${ }^{5}$ Various scholars have thus reminded us that locally-based deities are not readily portable, and that those who engaged in long-distance maritime trade needed to establish relationships with beings whose superior protection could extend well beyond the immediate vicinity. ${ }^{6}$

In consequence, the sea-ocean connections that have been fundamental in shaping Southeast Asian history are deeply implicated in the spread of universally applicable cosmologies and religions. Regardless of the distance from familiar waters, seafarers moving into the wider ocean could tap what Robin Horton has termed 'macrocosmic' religious beliefs to invoke deities, saints and divinities that transcended specific localities and cultures. As a corollary, when these revered figures were incorporated into localised 'microcosmic' spirit domains, the fundamental preoccupation

3 Peter N. Miller, 'The sea is the land's edge', in The sea: Thalassography and historiography, ed. P.N. Miller (Ann Arbor: University of Michigan Press, 2013), p. 10. Less insistent on this distinction are the contributions in Connecting seas and connected ocean rims: Indian, Atlantic and Pacific Oceans and China Seas migrations from the 1830s to the 1930s, ed. Donna R. Gabaccia and Dirk Hoerder (Leiden: Brill, 2011). In this context, see Martin Lewis, 'Dividing the ocean sea', Geographical Review 89, 2 (1999): 188-214.

4 For example, Barry J. Cunliffe, Facing the ocean: The Atlantic and its peoples, 8000 BC-AD 1500 (Oxford: Oxford University Press, 2001), p. 565; Michael N. Pearson, 'Littoral society: The concept and the problems', Journal of World History 17, 4 (2006): 353-74.

5 Philip Taylor, Goddess on the rise: Pilgrimage and popular religion in Vietnam (Honolulu: University of Hawai'i Press, 2004), pp. 217-18.

6 Anthony Reid, 'Islamization and Christianization in Southeast Asia: The critical phase, 1550-1660', in Southeast Asia in the early modern period: Trade, power, belief, ed. Anthony Reid (Ithaca: Cornell University Press, 1993), pp. 159-60. 
of coastal peoples - to ensure that all seagoing activities would meet with success was retained. ${ }^{7}$ Yet although the domestication of incoming religions has provided a major theme for historical research on the beliefs of Southeast Asia's land-dwelling communities, the same approach is less evident when one moves away from the shore. Based on the assumption that changes in maritime cosmologies are fundamental to the region's religious history, this article underscores Semple's contention that the 'many-sided' nature of human experience in the seas and oceans should receive the same attention as that of land-dwellers. ${ }^{8}$

\section{Indigenous spiritscapes and ambiguous shorelines}

'Seascapes', as Ian McNiven has shown in his study of Australian aboriginal societies, are best understood in terms of cosmologies that 'frame and constrain perception, engagement and use of seas'. For the coastal communities he describes, the sea is permeated by ambiguity, 'a dynamic medium with constantly changing colours, temperatures, waves, currents and tides. It is also a giver of life and a taker of life. The capricious nature of the sea, appreciated by all mariners, is consistent with a sea animated by sentient spiritual beings. ${ }^{9}$

McNiven's contention that Aboriginal seascapes should be conceptualised as 'animated spiritscapes' ${ }^{10}$ is particularly useful in the Southeast Asian context, where the seas, simultaneously life-supporting and potentially life-threatening, were (and are) a pivotal element in the world-view of maritime peoples. Fish and other forms of marine life provided the food without which the community would perish; seaborne communication supported trading networks that sustained communal livelihood; the sea could also be a place for ritual cleansing and healing. But the unseen forces that controlled even familiar waters could still bring about shipwreck, material loss and death, and stories abound of fishermen who have inexplicably disappeared at sea, abducted by malicious spirits or lured to their death by seductive spirit maidens. ${ }^{11}$ The very environment spoke to the possibility of some disaster, and traditional beliefs that coastal hills or islands are the upturned boat (bangka/wangka) of some legendary ancestor are frequently found in Southeast Asian cultures, the best documented being the stories attached to the island of Bangka, off the coast of Sumatra. ${ }^{12}$

7 See further Robin Horton, 'African conversion', Africa: Journal of the International African Institute 41, 2 (1971): 85-108.

8 Semple, Influences of geographic environment, p. 294. This article develops ideas in Barbara Watson Andaya, 'Rivers, oceans, and spirits: Gender and water cosmologies in Southeast Asia', TRaNS: Trans-Regional and -National Studies of Southeast Asia 4, 2 (2016): 239-63.

9 Ian J. McNiven, 'Saltwater people: Spiritscapes, maritime rituals and the archaeology of Australian indigenous seascapes', World Archaeology 35, 3 (2003): 332.

10 Ibid.: $329-49$.

11 For example, Sandra Pannell, 'Of gods and monsters: Indigenous sea cosmologies, promiscuous geographies and the depths of local sovereignty', in A world of water: Rain, rivers and seas in Southeast Asian histories, ed. Peter Boomgaard (Leiden: KITLV, 2007), p. 85; Tony Whitton, Roehayat Emon Soeriaatmadja and Suraya A. Afiff, The ecology of Java and Bali (Hong Kong: Periplus, 1996), p. 673.

12 E.P. Wieringa, Carita Bangka: Het verhaal van Bangka (Leiden: Vakgroep Talen en Culturen van Zuidoost-Azië en Oceanië, University of Leiden, 1990), pp. 52-3; see also Pierre-Yves Manguin, 'Shipshape societies: Boat symbolism and political systems in insular South-East Asia', in Southeast 
For coastal communities the ambiguity that pervaded all associations with the sea was registered most clearly at the shoreline, the transitional zone where sea and land conjoined. Although beaches and coasts were a tangible reminder of ancestral meetings and the arrival of founder figures, they could also resurrect painful memories of violent storms, of bloated bodies washed up in the tide and the wreckage of boats in which sailors had drowned. Unequivocally categorised by Semple as the 'most important geographical boundary', ${ }^{13}$ this liminal space had to be transversed by all seafarers, a cosmologically symbolic act that helps explain the rituals attached to any sea-borne departures, especially the launching of boats.

Anthropological studies of Southeast Asian coastal communities provide ample evidence of the ambiguity of the sea-land juncture. On the one hand, beaches and shorelines are often regarded as the domain of troublesome and even unfriendly spirits. Malay informants told the pioneering ethnographer, Walter Skeat (1866-1953), that spiteful female spirits were known to sit in crowds at river mouths, waiting to steal fish from the fishing stakes. ${ }^{14}$ More recent studies affirm that strand spirits might also try to frighten people away from fishing grounds, for example, by making the rocks slimy so that fishermen slip and fall, or hiding under the sand where they play unpleasant tricks and even inflict bodily pain. ${ }^{15}$ On the other hand, there are also accounts of benign beings and ancestral guardians who inhabit estuaries and shorelines, often in the form of a stone or a rock, and who offer protection from possible raids or attack. Against this background, it is worth noting that most of the petroglyphs (including a mask-like face) recently discovered on boulders on the beach at Santubong, in Sarawak, and tentatively dated between the tenth and thirteenth centuries, look towards the ocean. ${ }^{16}$

Yet these shoreline beings can be fickle allies, for normally benevolent guardian spirits can themselves be roused to anger, directing the same power that causes illness or skin disease among enemies towards individuals or the community in retaliation for perceived inattention or some other offence. ${ }^{17}$ Encountering the ambiguity of this spirit-laden world, even an otherwise sceptical European could be vulnerable to the force of belief. Sherard Osborne, the young midshipman in charge of a

Asia in the 9th to 14th centuries, ed. David G. Marr and Anthony C. Milner (Singapore: Institute of Southeast Asian Studies; RSPAS, Australian National University, 1984), pp. 187-213.

13 Semple, Influences of geographic environment, p. 242.

14 Walter William Skeat, Malay magic: Being an introduction to the folklore and popular religion of the Malay Peninsula (New York: Dover, 1967 [1900]), p. 327.

15 Jaime Biron-Polo, Rethinking Philippine popular symbols: Moments of domination and resistance in the province of Leyte (Quezon City: Research Forum, 1988), p. 64; Charles Zerner, 'Sounding the Makassar Strait: The poetics and politics of an Indonesian marine environment', in Culture and the question of rights: Forests, coasts and seas in Southeast Asia, ed. Charles Zerner (Durham, NC: Duke University Press, 2003), p. 66; Cynthia Chou, The Orang Suku Laut of Riau, Indonesia: The inalienable gift of territory (London: Routledge, 2010), p. 75.

16 Paul S.C. Taçon, Mohd. Sherman Sauffi and Ipoi Daton, 'New engravings discovered at Santubong, Sarawak', Sarawak Museum Journal 67, 88 (2010): 105-21. See further Ian J.M. McNiven and Liam M. Brady, 'Rock art and seascapes', in A companion to rock art, ed. Jo McDonald and Peter Veth (London: John Wiley, 2012), pp. 71-89.

17 Raymond Firth, 'Faith and scepticism in Kelantan village magic', in Kelantan: Religion, society, and politics in a Malay state, ed. William C. Roff (Kuala Lumpur: Oxford University Press, 1974), p. 201; Dirk Teljeur, The symbolic system of the Giman of South Halmahera (Dordrecht: Foris, 1990), pp. 104-5. 
British gunboat blockading Kedah in 1838, was alerted by his apprehensive Malay crew to the presence of a female hantu (spirit) walking along the shore where water and jungle met. 'An odd tremor, I am not ashamed to say, ran through my frame as I caught sight of what looked like the figure of a woman with drapery thrown around her ... again I looked and again I saw the same form'. However, the Malays assured him that she did not wish them harm, since she had not boarded the boat as some hantu laut (sea spirits) were wont to do. ${ }^{18}$ A century afterwards in Kelantan, on the west coast of the peninsula, the anthropologist Raymond Firth encountered similar beliefs in hantu who constantly paced the beach, even during the day. Though warning him that they could be easily annoyed, a Malay bomoh (shaman) also said their anger could be effectively negated by a combination of bribes (rice, pancakes, cigarettes, betel) and implied threats. 'I know your names ... Don't you do evil/To people walking along the edge of the strand'. ${ }^{19}$ In contemporary times the uncertainties associated with the shoreline are graphically personified in the restless female spirit, I Sabaria, 'the guardian of the edge' described by Indonesian fishermen in Mandar, Sulawesi. She 'always walks each day and night, always moving ... up and down the length of the coast' but, although it is never known when she will pass, it is she whose favour must be solicited if the catch is to be successful. ${ }^{20}$

\section{Moving away from the shore}

The reciprocal but at times uneasy relationship between humans and their spiritscapes has been most extensively researched among the nomadic groups who traditionally lived primarily on boats - the Moken of the Mergui Archipelago, southeast Thailand and northern Malaysia; the Sama Bajo found in island waters from the southern Philippines to eastern Indonesia; and particularly the Orang Suku Laut of the Riau-Lingga archipelago. ${ }^{21}$ Occasionally, however, historical sources also offer a glimpse of how such groups approached the unseen forces that controlled local waters. In the early nineteenth century, for instance, Munsyi Abdullah (1796-1854) remarked on the homage offered by Orang Laut to the powerful hantu of an unusual rock at the mouth of the Singapore River. Hung around with the cloth streamers (panji-panji) that customarily decorated a Malay keramat (sacred) site, this formation was known as Batu Kepala Todak because it was shaped like the head of the swordfish associated with Singapore's legendary history. ${ }^{22}$ The Orang Laut said that if they failed

18 Sherard Osborn, The blockade of Kedah in 1838: A midshipman's exploits in Malayan waters (Singapore: Oxford University Press, 1987 [1857]), p. 245.

19 Firth, 'Faith and scepticism', p. 211.

20 Zerner, 'Sounding the Makassar Strait', p. 65.

21 The literature is extensive, but see Cynthia Chou, 'Research trends on Southeast Asian sea nomads', Kyoto Review of Southeast Asia 7, 2006, https://kyotoreview.org/book-review/research-trends-on-southeast-asian-sea-nomads/ (last accessed 3 May 2017). Older but still useful overviews are David E. Sopher, The sea nomads: A study based on literature of the maritime boat people of Southeast Asia, Memoirs of the National Museum No. 5 (Singapore: National Museum, 1977 [1965]), p. 279 ff. and Nicholas V.C. Polunin, 'Traditional marine practices in Indonesia and their bearing on conservation', in Culture and conservation: The human dimension in environmental planning, ed. Jeffrey A. McNeely and David C. Pitt (New York: Croom Helm, 1987), pp. 155-80.

22 For the account of the swordfish attack on Singapore, see C.C. Brown, Sejarah Melayu or Malay Annals, with a new introduction by R. Roolvink (Kuala Lumpur and London: Oxford University Press, 1970), p. 40. 
to pay due respect to the hantu, they would surely all be destroyed when they entered or left the adjacent strait (Jikalau tiada kami hormati akan dia, apabila kami keluar masuk Selat ini kelak nescaya dibinasakannya akan kami sekalian). ${ }^{23}$

In this passing reference, Abdullah has recorded the mixture of respect, apprehension and fear with which sea spirits were approached - attitudes that coalesce as a little-explored but underlying theme in Southeast Asia's maritime history. ${ }^{24}$ From the time they launch their boats, many seafarers still encounter a veritable army of spirit beings that inhabit 'beaches, capes and points, islands, submerged and exposed rocks, spits, sandbars, submerged reefs, areas of deep water, tidal areas, areas of strong currents and whirlpools'. ${ }^{25}$ While most sea beings were approached with caution, some could be well disposed and sympathetic to human needs, like the 'goddesses of the sea' invoked in the chant of a Vietnamese fishing community, ${ }^{26}$ or the outsize ancestors renowned for their exploits who were recalled in oral histories. The shrines and graves linked to their life-stories functioned as sacred land-based sites for offerings that petitioned protection for those at sea. One such place was the keramat site at the base of Bukit Jugra (a landmark hill on the coast of the Malaysian state of Selangor). According to legend, the thigh bone of the celebrated seafarer, Nakhoda Ragam (popularly associated with Sultan Bolkiah, the fifth ruler of Brunei) was buried at this spot, which Skeat says subsequently became a 'famous shrine'. Nakhoda Ragam's ship broke up to form the islands off the Melaka coast. ${ }^{27}$

The spirit of a human lost at sea might also act as a sympathetic mediator who could temper supernatural perversity. Hantu anger at some apparent slight might have caused the death of a Tamil (Malay: Keling) sea captain when his trading ship passed a prominent Singapore headland (tanjung), but on the renamed 'Tanjung Keling' his grave served as a keramat for petitioning help or protection. ${ }^{28}$ Fishermen could also call on their own forebears who were also lost at sea but were remembered at the place where their boat had foundered - a reef, a sandbar, a whirlpool, or perhaps a rock that miraculously formed the shape of a perahu. ${ }^{29}$ In the mid-seventeenth century the Jesuit priest Francisco Colin (1592-1660) remarked that in pre-Christian times, when 'there was an anito del mar [spirit of the sea], to whom [the Filipinos] commended their fisheries and navigations', it was quite possible for eminent men to anticipate a future status as deities of the maritime world. He recorded the story of one old man from the island of Leyte who instructed his followers to place his coffin in a house near the coast, 'in order that

23 Karya lengkap Abdullah bin Abdul Kadir Munsyi, vol. 3, Hikayat Abdullah, ed. Amin Sweeney (Jakarta: Kepustakaan Populer Gramedia and École française d'Extrême-Orient, 2006), p. 365.

24 As noted by Chou, The Orang Suku Laut of Riau, pp. 74-5, 88.

25 Pannell, 'Of gods and monsters', p. 10.

26 Maurice Durand and Tranh Ham Tan, 'Culte de la baleine: Chant des pêcheurs de Truong-Dong', Bulletin de la Société des études indo-chinoises de Saigon 28, 2 (n.s. 2) (1953): 183-209.

27 For details of this legend, see Skeat, Malay magic, p. 166; D.F.A. Hervey, 'Malacca legends of Nakhoda Ragam', Notes and Queries 2 (Kuala Lumpur: Government Printing Office for Journal of the Straits Branch of the Royal Asiatic Society (1885), pp. 40-46.

28 P.J. Rivers, 'Keramat in Singapore in the mid-twentieth century', Journal of the Malaysian Branch of the Royal Asiatic Society 76, 2 (2003): 102.

29 Pannell, 'Of gods and monsters', p. 81. 
he might be recognized as a god of navigators, who were to commend themselves to him' 30

In contrast to sympathetic ancestor figures, many sea spirits have a reputation for being mischievous, disagreeable, or even malevolent, and a fisherman might therefore plead with them to allow him to fish undisturbed or nap peacefully when he is tired, or simply ask that the hantu return to their abode. ${ }^{31}$ Such spirits can, however, be amenable to a negotiated relationship beneficial to both parties. In his classic study of a fishing village in Kelantan Raymond Firth thus described how fishermen 'adopted' specific hantu laut who, in return for regular offerings, would protect the boats of their clients and ensure that they netted good catches. ${ }^{32}$ As these accounts suggest, it was necessary to approach even kindly spirits with respect, for they are jealous custodians of their own domains and of the fish and marine creatures under their surveillance. More than three hundred years after Father Colin described the aspirant anito del mar, an anthropologist also working in Leyte recorded a panampit (invocation addressed to the spirits of the sea) that pleads with the 'ruler of the sand, ruler of the rocks, and the ruler of the shores', asking them to release the fish over which they exert authority and 'give us some of them'. ${ }^{33}$ A Malay mantra from the 1930 s is even more inclusive, inviting the 'lords of the sea, bays, river reaches, capes, shallows and estuaries' to gather and receive their gifts of a sacrificed goat, yellow rice, arak, eggs, and other ritual items. 'Come old, come young, come short, come tall, those who are blind can be led, those who are lame can use a stick. We pray for your help to guard us.' 34

Although such spirits could be both demanding and capricious, local fishermen were aware of their characteristics and temperaments, and appreciated the need to foster goodwill in order to ensure the success of any seaborne undertaking. Without their unseen assistance the most able navigator could encounter unexpected hazards, for unforeseen perils lurked even in well-travelled waterways. For example, the Jesuit missionary Francisco Alcina (1610-74) recorded that Filipinos called the sea route between northern Samar and southern Luzon balikuatan, meaning tortuous or perverse. It was said to be the 'most dangerous and most feared by all the navigators', and the whirlpools, choppy waves, and waterspouts were all regarded by Filipinos as pababaliw, the work of hostile sea spirits. ${ }^{35}$ But while Alcina praised

30 Francisco Colin, 'Native races and their customs' (from Labor Evangélica, 1663), in The Philippine Islands 1493-1898, ed. Emma Blair and James Alexander Robertson (Cleveland: Arthur H. Clark, 1903-09), vol. 40, p. 72.

31 Uniawati, Fungsi mantra melaut pada masyarakat suku Bajo di Sulawesi Tenggara (Kendari: Kantor Bahasa, Propinsi Sulawesi Tenggara, 2006) pp. 26, 27-8, 37. On the spitefulness of sea spirits, see Zerner, 'Sounding the Makassar Strait', p. 65; Natasha Stacey, Boats to burn: Bajo fishing activity in the Australian fishing zone (Canberra: ANU Press, 2007), p. 33.

32 Raymond Firth, Malay fishermen: Their peasant economy (London: Kegan Paul, Trench, Trubner \& Co., 1946), pp. 13, 118-19.

33 Biron-Polo, Rethinking Philippine popular symbols, p. 59.

34 Ishak bin Ahmad, 'Malay fishermen's superstitions', Journal of the Malayan Branch of the Royal Asiatic Society 19, 1 (1941): 131-6.

35 Francisco Alcina, S.J., History of the Bisayan people in the Philippine Islands. Evangelization and culture at the contact period. Historia de las islas e indios visayas ... 1668, ed., trans. and annotated by Cantius J. Kobak, O.F.M. and Lucio Gutiérrez, O.P., pt 1, bk 2, vol. 2 (Manila: University of Santo Tomas Publishing House, 2004), pp. 255-63, 268, 270. 
Filipino navigational skills, he does not mention the propitiation that would have been necessary to solicit the goodwill of supernatural forces by recognising their superior knowledge. Documented many years later, albeit in a less challenging environment, such solicitation is captured in a Malay invocation to the sea spirit guarding the route to Pulau Pinang, 'I do not know the hidden snags/I do not know where tree stumps are/ I do not know the rocks and reefs/ But you know'. ${ }^{36}$ The strategies used to establish a beneficial relationship with sea spirits is thus a recurring motif in the cultures of maritime communities. By the same token, because of the everpresent possibility of some unforeseen catastrophe, it was important to offer due thanks to sea spirits after the safe completion of any voyage. In 1888 a French doctor travelling by boat along the Vietnamese coast thus described how three soldiers, unaccustomed to rough weather, offered candles, poultry, rice wine, pork, and fruits, to the 'spirit of the sea' in return for the protection they had received. ${ }^{37}$

The belief that control over water, as on the land, was divided among local spirits also meant that without their approval fishing or any other venture would be unsuccessful. The prestation of food - special types of bananas, chicken, coconuts, and cigarettes - is necessary because these unseen beings, like village headmen or district officers, require flattery, bribes and 'sweet things' as recompense for permission to fish in their domains. ${ }^{38}$ Makassar sailors who began sailing to northern Australia at least from the eighteenth century therefore placated the karaeng (Makassarese, meaning lords) that inhabited certain large shoreline rocks regarded by Aboriginals as sacred by offering 'food, goods and money'. By recognising the status of these powerful spirits, now locally remembered as 'Walkangi Karei' (i.e. karaeng), the Makassarese believed that their claims to harvest trepang (bèche-de-mer, Holothuria edulis) in nearby waters would be acknowledged. ${ }^{39}$

Conversely, failure to follow prescribed rituals of gratitude and offer acceptable compensation could incur supernatural anger, so that a torn fishing net, a disappointing catch, a broken mast, an unexpected storm, a sudden illness could all be attributed to spirit reprisal for some infraction. ${ }^{40}$ According to the Orang Laut, even the much-respected raja laut (king of the sea), will overturn boats when annoyed. ${ }^{41}$ In establishing the communication necessary to mollify and assuage such beings, the relationship between humans and the sea spirits can be likened to a contract; deference, customary observance and the 'payment' of appropriate offerings, often through the use of a spirit medium, will be translated into favour and success, but inattention to correct procedure or some unwitting transgression can result in calamity. ${ }^{42}$ Indeed,

36 Skeat, Malay magic, pp. 279, 641.

37 Paul Neis, 'Sur les frontières du Tonkin', Tour du Monde 55 (1888): 385, 388.

38 Zerner, 'Sounding the Makassar Strait', p. 74; Chou, The Orang Suku Laut of Riau, pp. 88-9; See further Andaya, 'Rivers, oceans and spirits', pp. 251-2.

39 Ronald M. Berndt and Catherine H. Berndt, Arnhem Land: Its history and people (Melbourne: F.W. Cheshire, 1954), p. 45.

40 Zerner, 'Sounding the Makassar Strait', p. 66.

41 Cynthia Chou, 'Borders and multiple realities: The Orang Suku Laut of Riau, Indonesia', in Centering the Margin: Agency and narrative in Southeast Asian borderlands, ed. Alexander Horstmann and Reed L. Wadley (New York: Berghahn, 2006), p. 120.

42 Jaime B. Polo, 'Of metaphors and men: The Binalayan fish corral ritual as a contact in a social spectrum', Philippine Sociological Review 33, 3-4 (1985): 54-63. 
belief in this supernatural propensity to punish even the apparently innocent was widespread. In early twentieth-century Sarawak, for instance, Dayaks were convinced that a cholera epidemic was caused by some malicious spirit that came from the sea and killed and ate its human victims. ${ }^{43}$ In the same period an authority on Malay culture reported that Sultan Mahmud of Johor, murdered in 1699, was thought to haunt the coast of Kelantan. Transposed into a powerful and vengeful hantu laut, he could inflict fever and chills if offended. ${ }^{44}$ Today many Javanese still believe that if angered, Ratu Kidul, the beautiful Princess of the Southern Seas, can punish villagers with disease, take drowned sailors to her underwater palace, or cause earthquakes and tidal waves. ${ }^{45}$

Though indigenous sea spirits were typically only vaguely envisaged, even when addressed by name and accorded a personality, others were thought to assume a physical form. The European sailors who first moved into Southeast Asian waters brought with them an entrenched belief in strange sea beings, and encounters with the manatees and dugong found in warm coastal waters from Africa to Japan, evidently encouraged new stories of mermaids. Some early reports even recorded their capture, claiming that when dissected, 'their internal structure was found to be in all respects conformable to the human'. ${ }^{46}$ However, in his magisterial account of the Visayas, Father Alcina made a clear distinction between the dugong or 'pese mullier' and the 'pesces macho y hembra', the male and female fish people. As he explained in his text, these 'sirenia' did not have a fish's tail, like the merfolk of Spain, but resembled a human being with webbed feet (as shown by the tracks they left in the sand) and hands. Called kataw by locals, they were often seen sunning themselves on small islands. In the sketch that accompanies the 1784 version of his manuscript, these 'catau hombre' and catau baya' (male and female kataw) are shown gambolling in the sea, clearly distinguished from the other forms of marine life, including the dugong. ${ }^{47}$ The Dutch minister François Valentijn (1666-1727), whose monumental work is still a primary source for scholars of Indonesia, devoted considerable attention to 'well authenticated' reports of zee-menschen and zee-wyven found around Ambon, with one mermaid allegedly presented to the governor. ${ }^{48}$ Other Dutch East India Company officials and Christian ministers also affirmed European and local sightings of human-like beings, and belief in the existence of 'humanoid mermaids' remained widespread in Europe well into the nineteenth century. ${ }^{49}$ In much of the non-Western

43 Edwin H. Gomes, The Sea-Dyaks of Borneo (London: Society for the Propagation of the Gospel in Foreign Parts, 1907), p. 41.

44 Richard O. Winstedt, Shaman, Saiva and Sufi: A study of the evolution of Malay magic, rev. ed. (London: Routledge and Kegan Paul, 1961 [1925]), p. 11.

45 Mark Woodward, Java, Indonesia and Islam (London: Springer, 2010), p. 88.

46 James Emerson Tennent, Sketches of the natural history of Ceylon, with narratives and anecdotes ... (London: Longman, Green, Reader, and Dyer, 1868), p. 70.

47 Historia de las islas e indios visayas del Padre Alcina, 1668, ed. Maria Luisa Martín-Merás and Maria Dolores Higueras (Madrid: Instituto Historico de Marina, 1975), p. 289. For a translation, see Kobak and Gutiérrez, History of the Bisayan people, pp. 299-301, 363.

48 François Valentijn, Beschrijving van oud en nieuw Oost-Indiën ..., 5 vols, folio (Dordrecht and Amsterdam, 1727), vol. 3, 1, pp. 330, 340-41. See further Siegfried, 'Ware kennis in Oud en Nieuw Oost-Indiën van François Valentijn: Beschrijving van paradijsvogels en "zee menschen", Nieuw Letterkundig Magazijn 29 (2011): 37-44.

49 Sabine Baring-Gould, Curious myths of the Middle Ages (London: Rivingtons, 1868), pp. 289-92; Jan 
world, however, the assumption that the assistance of local sea-dwelling spirits (often conceptualised as female) will be necessary for any maritime venture still persists. Nonetheless, as pearl-divers in eastern Indonesia know full well, bewitching sea women can be exacting mistresses, demanding constant gifts in return for guidance to rewarding sites. Others, hostile towards all men, might take pleasure in luring boats on to a reef, while old crones, intent on mischief, can inhabit submerged rocks on which an unwary vessel may founder. ${ }^{50}$

Sea spirits could also appear in the form of marine creatures, notably dugong, giant squid, octopus, whale sharks (Rhincodon typus) and whales. ${ }^{51}$ Although such creatures could be hunted (but subject to significant restrictions), the porous nature of human/non-human boundaries meant they could also be viewed as ancestors willing to assist deserving communities. The Giman people of South Halmahera (eastern Indonesia), for instance, recall a guardian spirit, Kawán Karoput (Mrs. Squid), who captured a Dutch ship by attaching itself to the hull. This ultimately led to the local appropriation of the ghostly shipwrecked captain as another community custodian. ${ }^{52}$ Often the appearance of these large sea creatures is a portent of danger, but legends could also describe the sympathy they had displayed for individuals lost at sea. A seventeenth-century Cham manuscript from central Vietnam records that a local man, returning from Kelantan after a period of studying Malay magic, was drowned when his boat sank in a storm. Encountering the drifting body, a whale carried the corpse back to shore, and was showered with honours by a grateful community. ${ }^{53}$

Given such attitudes, it is not surprising to find ancient cults dedicated to whale sharks and whales, especially along seasonal migration routes. On the island of Lembata (eastern Indonesia), the skulls of whales were once stored in temples and venerated like the skulls of ancestors. The hunting of whales was itself a sacred act, with special rituals conducted near a whale-shaped boulder. In the view of one authority, 'the whale may very well be comparable to rice in the religions of other Indonesian peoples'.$^{54}$ In fishing villages along the coast of Vietnam the whale cult was especially elaborate. A major temple dated to 1762 , located about two hundred kilometres from Ho Chi Minh City, contains over a hundred whale skeletons as

Bondeson, The Feejee mermaid and other essays in natural and unnatural history (Ithaca: Cornell University Press, 1999), p. 62.

50 Patricia Spyer, The memory of trade: Modernity's entanglements on an eastern Indonesian island (Durham and London: Duke University Press, 2000), pp. 17-18, 137-8; Pannell, 'Of gods and monsters', pp. 83-5.

51 Lance Nolde, 'Great is our relationship with the sea: Charting the maritime realm of the Sama of Southeast Sulawesi', Explorations 9 (2009): 15-33; Zerner, 'Sounding the Makassar Strait', p. 68.

52 Teljeur, The symbolic system of the Giman, p. 108.

53 Nguyen Quoc Than, 'The whale cult in Central Vietnam: A multicultural heritage in Southeast Asia', in Memory and knowledge of the sea in Southeast Asia, ed. Danny Wong Tze Ken (Kuala Lumpur: Institute of Ocean and Earth Science, University of Malaya, Monograph Series 3, 2008), pp. 77-96. Stories of fishermen saved by whales and whale sharks are also found among the Sama Bajo, who therefore regard killing or eating such creatures as taboo, or pemali. Natasha E. Stacey, Johanna Karam, Mark G. Meekan, Samuel Pickering and Jotham Ninef, 'Prospects for whale shark conservation in Eastern Indonesia through Bajo traditional ecological knowledge and community-based monitoring', Conservation and society 10, 1 (2012): 68.

54 R.H. Barnes, 'Lamalerap: A whaling village in eastern Indonesia', Indonesia 17 (Apr. 1974): 147-59. 
well as an ancient altar dedicated to the whale deity, 'Lord Fish'. Whales were never hunted in Vietnam, and there are numerous stories of fishermen or sailors who were helped to safety by whales. The most well-known of such individuals is reputed to be the emperor Gia Long (1802-20), who issued several decrees conferring the title 'Admiral of Southern Sea' on whales; in later years beached whales received other honours, such as 'Giant Jade-scaled Spirit of the South Seas', awarded by Emperor Tu Duc in 1880. In the past theatricals were mounted along the beach for the pleasure of Lord Fish and the sea goddesses in hopes of ensuring a successful fishing venture. Still today the individual who discovers the body of a beached whale is recognised as its son, and is required to go into mourning as he would for a parent. $^{55}$

Cults devoted to migrating and ever-moving creatures like the whale are of particular relevance to this article. In contrast to the spirits linked to specific localities, such as whirlpools, reefs or capes, they occupy a boundless world and roam over vast distances. The transitions this makes possible are evident in stories attached to Varuna, the Hindu God of the Ocean, who was initially tied to the coasts, holding sway, says the ancient Tamil text, the Tolkappiyam, over the littoral tracts. The fourteenth-century scholar Naccinarkiniyar noted that 'when their fishing expedition fails, [the fisher people] assemble with their children on the sea-coast, plant there the horn of the shark and bless Varunan; then he manifests himself. ${ }^{56}$ Nonetheless, the Rig Veda presents an alternative image of Varuna as a sea god with whom devotees 'moving with the waves ... as if on a swing for joy' can commune. In this manifestation he has been envisaged as carrying Vedic teachings across the oceans to Hinduism's farthest outpost, Bali, riding on the back of his vehicle (a makara, represented as a crocodile or a large fish such as a shark). ${ }^{57}$ In the same mode, the perception that new religious beliefs were transmitted via seaborne connections is nicely captured in a chronicle from eastern Borneo depicting the first Muslim teacher who arrives on the back of a swordfish. ${ }^{58}$ Varuna on his makara and the 'gentleman astride a swordfish' (Tuan Tunggang Parangan) provide a bridge into a consideration of the ways in which the traditions and practices found in Southeast Asian seas were reshaped as they encountered new deities who wielded authority over the wider ocean environment.

55 Michael Parnwell, 'Vietnamese whale worship in comparative perspective', in The great diversity: Trajectories of Asian development, ed. Camilla Brautaset and Christopher M. Dent (Wageningen: Wageningen Academic, 2014), pp. 83-102; Nguyen Than, 'The whale cult in Central Vietnam', p. 87; Sandra Lantz, Whale worship in Vietnam (Uppsala: Swedish Science Press, 2009); Maurice Durand and Tranh Ham Tan, 'Culte de la baleine', p. 186.

56 V. Muragan, trans., Tolkāppiyam in English (Chennai: Institute of Asian Studies, 2000), p. 375; A.L. Basham, The wonder that was India (New York: Grove, 1954), p. 313; P.T. Srinivasa Aiyangar, 'Environment and culture', http://yabaluri.org/TRIVENI/CDWEB/EnvironmentandCulturejuly.htm (last accessed 1 Sept. 2009).

57 David Frawley, Gods, sages and kings: Vedic secrets of ancient civilization (Salt Lake City, UT: Passage, 1991), pp. 59-60; The Bhagavad Gita: Twenty-fifth anniversary edition, trans. Winthrop Sargeant, ed. Christopher Key Chapple (Albany: SUNY Press, 2009), p. 441.

58 De kroniek van Kutai, ed. Constantinus A. Mees (Santpoort: Leiden University, 1935), p. 240. See further Pierre-Yves Manguin, 'The merchant and the king: Political myths of Southeast Asian coastal polities', Indonesia 52 (Oct. 1991): 41-54. 


\section{Oceans, seas and protective deities}

In the seas of Southeast Asia the attention spirits demanded and their often vacillating responses were tempered by centuries of accumulated human experience and a storehouse of cultural knowledge that facilitated interaction with the non-human world. The situation was rather different when sailors moved into what Malays called the laut jerebu, 'the sea where land is no longer in sight'. ${ }^{59}$ Despite the depth of the maritime tradition, we should not see Southeast Asia as exceptional to the coastal areas of Europe, where 'the majority of early modern men and women' regarded the sea as 'a dangerous place, which was associated with disorder, chaos and death'. ${ }^{60}$ Shipwrecks and drownings were common, and there were few families who had not been affected by some tragedy. Ocean-going vessels could capsize in heavy seas, founder on a hidden reef or fall victim to some pirate attack. One of the most terrifying experiences was probably the giant or 'rogue' waves that a ship could encounter in otherwise calm waters. ${ }^{61}$ Embarkation for a long-distance voyage was thus a perilous venture, and sources from the early modern period are replete with accounts of ships that had run aground in unfamiliar waters. The conviction that such an undertaking would inevitably result in death is evident in an episode related by the Flemish merchant Jacques de Coutre during his visit to Ayudhya in 1595. An elite woman, whose sons had been selected to lead a royal embassy to Portugal 'made great pilgrimages to their idols and demons', and gave lavish gifts to the monks. Herself unable to express any objection to the king's wishes, she pleaded that they act on her behalf and 'beseech the gods to prevent that journey'. ${ }^{62}$

The apprehension expressed by this anxious mother was not easily allayed, and similar feelings of trepidation have not disappeared even with the advances of modern technology. In the Philippines a recent study has stressed the fear and uncertainty conveyed by the Visayan term mari-it, applied to any deep sea area far from the more familiar environment of estuaries and coastal waters, and regarded as populated by alien and probably malign spirits. ${ }^{63}$ With the expansion of trade beyond wellknown domains, the universality and portability of deities allied to larger religious systems would have become particularly attractive. The Qur'an speaks of the comfort Allah provides when 'there comes a storm wind and the waves come from everywhere', for 'if He willed, He could still the wind' (Surah 10: 22; Surah 42: 33-4). To be assured of this assistance, medieval Islamic navigators began developing written guides for pilots that could locate the direction of Mecca while they were at sea, so that

59 R.J. Wilkinson, A Malay-English dictionary (Singapore: Kelly \& Walsh, 1903), p. 593.

60 Raingard Eber, 'Fear of water and floods in the Low Countries', in Fear in early modern society, ed. William G. Naphy and Penny Roberts (Manchester: Manchester University Press, 1997), p. 62.

61 'Extreme storm waves' ('rogue' or 'freak') are more than twice the size of surrounding waves and come unexpectedly from directions other than those of the prevailing wind and current. The causes have not yet been fully established. 'What is a rogue wave?', http://oceanservice.noaa.gov/facts/ roguewaves.html (last accessed 19 June 2015).

62 The memoirs and memorials of Jacques de Coutre: Security, trade and society in 16th-and 17th-century Southeast Asia, ed. Peter Borschberg, trans. Roopanjali Roy (Singapore: NUS Press), pp. 113-14.

63 Alicia P. Magos, 'The concept of mari-it in Panaynon maritime worldview', in Fishers of the Visayas, ed. Iwao Ushijima and Cynthia Neri Zayas, Visayas Maritime Anthropological Studies 1, 1991-1993 (Diliman, Quezon City: CSSP Publications, University of the Philippines, 1994), pp. 305-55. 
their prayers would be effective. ${ }^{64}$ In contemporary times, Mandar fishermen may propitiate local spirits when they are close to home, but when they sail towards the open seas, they turn to Allah and the prophets to ensure a successful voyage and a safe return. ${ }^{65}$

Although the application of similar arguments to ancient ocean voyages such as those from the Indonesian archipelago to Madagascar is problematic, it seems safe to assume that many of the small images, seals, and amulets invoking Shiva, Vishnu and other deities discovered in early Southeast Asian sites were carried by Indian traders and sailors as talismans in order to guarantee a propitious voyage. ${ }^{66}$ Something of this comes through in the brief Sanskrit inscriptions on several irregularly-shaped and unworked stones from Palembang, in southeast Sumatra. Dated to the seventh or eighth centuries, they speak of a 'successfully accomplished journey', noting that it is 'for the welfare and happiness of all living beings'. One authority has suggested that these stones were tied to ropes and used as anchors in shallow waters following a ship's safe arrival from India. If so, the undercurrents of relief and thankfulness can be interpreted as indicative of the anxiety and fear generated by voyage across the sea'. ${ }^{67}$ In Bali, Indian perceptions of the ocean as defiling would have reinforced views of the sea as an unclean abode of demons, but the stress on water in purification rites also helped counter the threatening aspects of the shoreline and transform the beach into a place of ritual cleansing. In the sixteenth century a chain of temples around Bali was founded to honour the sea gods, including Baruna (Varuna), while sacred masks are regularly purified in the sea, which has become a source of powerful holy water and the final resting place of ashes after cremation. ${ }^{68}$

Belief in a world linked by 'unbounded oceans' assumed new dimensions as Buddhism expanded from India into eastern Asia. Writing in the twelfth century, for instance, a Japanese Buddhist priest explained that he could not travel to India because of the distance and his own ill health. As he walked along the beach he found a small but beautiful stone, which reminded him that the water poured over sacred Buddhist images flowed into the larger ocean that connected Japan and India. ${ }^{69}$ In Southeast Asia a Sanskrit inscription from the Malay Peninsula dated to around 450-500 CE supplies early evidence of the reach of Buddhist teachings. Erected near a Buddhist temple, it reiterates the concerns of the Sumatran inscriptions in expressing the hope of a 'great sea captain, Buddhagupta' (who may have been locally resident) that he and his fellow travellers would be 'successful in their

64 Hyunhee Park, Mapping the Chinese and Islamic worlds: Cross-cultural exchange in pre-modern Asia (Cambridge: Cambridge University Press, 2012), p. 185; Economic history of medieval India, 1200-1500, ed. Irfan Habib (New Delhi: Pearson Education), p. 121.

65 Zerner, 'Sounding the Makassar Strait', p. 71.

66 Kenneth R. Hall, A history of early Southeast Asia: Maritime trade and societal development (Lanham, MD: Rowman and Littlefield, 2010), p. 57.

67 K.V. Ramesh, 'Reconsidering cultural intercourse between India and Southeast Asia: An epigraphic report', in Ancient and medieval commercial activities in the Indian Ocean: Testimony of inscriptions and ceramic-sherds, ed. Noboru Karashima (Tokyo: Taisho University, 2002), pp. 153, 218.

68 Hildred Geertz, The life of a Balinese temple: Artistry, imagination and history (Honolulu: University of Hawai'i Press, 2004), pp. 40, 59.

69 See Osamu Kondo, 'Japan and the Indian Ocean at the time of the Mughal empire, with special reference to Gujarat', in The Indian Ocean: Explorations in history, commerce and politics, ed. Satish Chandra (New Delhi: Sage, 1987), p. 175. 
voyage'. ${ }^{70}$ In a similar mode, pilgrims travelling from China to India testified to the power of prayers offered to Avalokiteshvara (Guanyin in China), who was specifically associated with cults for mariners. ${ }^{71}$ On his return from India, the fifth-century pilgrim Faxian was a passenger on a ship that encountered a 'violent gale, with tempestuous rain, at which the travelling merchants and traders who were [going back to China] were much frightened'. Faxian invoked Guanyin, 'the Hearer of Prayers' and the guardian of shippers, and the vessel was saved. ${ }^{72}$

Probably the most renowned of the early trans-oceanic voyages were the 'Ming expeditions' of the early fifteenth century, led by the Muslim eunuch Zheng He, who was clearly concerned to marshal all the supernatural assistance possible. During the voyages prayers were offered daily to give thanks for past protection and request assistance for the future. Incense was constantly burnt before an image of the sea goddess, Tian Fei, commonly known as Mazu (great grandmother), who was revered by Buddhists and Daoists as Queen of Heaven and often equated with Guanyin, the Bodhisattva of Compassion. During the fifth voyage, when a Buddhist monk was on board, her intervention saved the fleet from storms, and following his return Zheng He set up a tablet in her honour. ${ }^{73}$ While sailing along the coasts of southern China and Hainan offerings were made at locations dedicated to Tian Fei or other deities. The most elaborate ritual was staged at Cape Varella on Vietnam's easternmost point, where coral reefs in surrounding waters presented considerable danger to shipping. A prominent rock on the promontory was popularly compared to the head of the Buddha, and at this 'Holy Mountain' Zheng He's sailors fasted and bathed for three days, venerated the Buddha, offered prayers, and set lighted lamps and miniature boats on the sea to simulate a safe voyage and avert calamity. ${ }^{74}$ Yet as the fleet sailed into unknown waters, Zheng $\mathrm{He}$ also recognised that he should acknowledge the authority of other deities, especially in the cosmopolitan environment of the Indian Ocean. Reaching Sri Lanka in 1409 on his third voyage, for example, Zheng He erected a tablet in Chinese in honour of the local 'Buddha' who reigned over the sea in this region. Accompanying inscriptions in Tamil venerated Tenavari-nayanar, an avatar of Vishnu, while the Persian version praised Allah and Islamic saints. ${ }^{75}$ As a telling

70 John Guy, 'Tamil merchants and the Hindu-Buddhist diaspora in early Southeast Asia', in Early interactions between South and Southeast Asia: Reflections on cross-cultural exchange, ed. Pierre-Yves Manguin, A. Mani and Geoff Wade (Singapore: ISEAS, 2011), p. 253.

71 John Guy, 'Introducing Southeast Asia', in Lost kingdoms: Hindu-Buddhist sculpture of early Southeast Asia, ed. John Guy (New York: Metropolitan Museum of Art; New Haven: Yale University Press, 2014), pp. 8-10.

72 Paul Wheatley, The Golden Khersonese: Studies in the historical geography of the Malay Peninsula before A.D. 1500 (Kuala Lumpur: University of Malaya Press, 1961), pp. 38-9.

73 Claudine Lombard Salmon, 'La communauté chinoise de Makasar. Vie religieuse', Toung Pao, 2nd ser., 55, 4-5 (1969): 272-3; Vivien-Lee Nyitray, 'Becoming the Empress of Heaven: The life and bureaucratic career of Mazu', in Goddesses who rule, ed. Elisabeth Benard and Beverley Moon (Oxford: Oxford University Press, 2000), pp. 165-80. I am grateful to Ivana Pražić for these references.

74 W.W. Rockhill, 'Notes on the relations and trade of China with the eastern archipelago and the coasts of the Indian Ocean during the 14th century. Part II', T'oung Pao 16, 1 (Mar. 1915), pp. 96-7; Ma Huan, Ying-yai Sheng-lan: The overall survey of the ocean's shores [1433], ed. and trans., J.V.G. Mills (Cambridge: Cambridge University Press for the Hakluyt Society, 1970), p. 309.

75 J.J.L. Duyvendak, China's discovery of Africa (London: Arthur Probsthain, 1949), p. 29; Arthur Cotterell, China: A concise cultural history (New York: Penguin, 1990), p. 205. 
reminder of the cross-cultural fertilisation fostered among maritime voyages, the stele erected by Zheng $\mathrm{He}$ in 1416 provided a vivid description of the ocean terrors and attributed his survival to the protection of both Tien Fei and of 'Mecca', his own Muslim faith. ${ }^{76}$

Texts and stories associated with Theravada Buddhism brought other sources of assistance for long-distance travellers. Both canonical and 'apocryphal' (i.e. locally composed) jataka, stories of the Buddha's previous lives, contain frequent references to voyages across oceans, but sea spirits are now placed firmly under the Buddhist umbrella. ${ }^{77}$ Rather than representing a potential danger, they are transformed into dewata, beings who protect those 'endowed with morality, with dharma and with truth-speaking'. One of the most prominent dewata was Manimekhala, who had been neglectful of her duties as a sea guardian, but who redeemed herself by saving the future Buddha when his ship foundered en route to Suvarnabhumi (Southeast Asia, probably referring to the Malay Peninsula). Another jataka records that the Buddha himself was once 'a supremely able ship's captain' named Supāraga, who had acquired great knowledge of the ocean. The jataka relates how a vessel that set out from India for Suvarnabhumi was engulfed by such terrible storms that the traders aboard feared for their lives. Some prayed to the gods, 'some entreated the Ocean itself; some muttered various spells, while others duly abased themselves before Devi'. However, because of his great store of merit, Suparaga was able to deflect the wind and currents so that the ship could alter course. 'A following wind and a calm sea allowed [it] to return with the ease of a magic conveyance'. Guided by the spirits of the sea, who loved Supāraga, the traders dredged up stones and pebbles only to find them transformed into silver, gold and precious gems. Reaching their home port safely, 'in an outburst of joy, they affectionately sang the praises of Supāraga' ${ }^{78}$

The spread of Islam in Southeast Asia, linked to the growing presence of Muslim traders, is generally dated to the thirteenth century. In the process it introduced another body of ocean-going saints, most of whom were associated with Sufism. In the present context it is worth noting that metaphors comparing the Qur'an to an ocean containing great treasures were a particular favourite among Sufi scholars. Al-Ghazali (d. 1111), for example, exhorted Muslims 'to sail through its depths in order to see its amazing things, to travel to its islands to pick its delicacies, to dive to its bottom and become rich from obtaining jewels'. However, although a voyage across the sea of faith holds out great possibilities for spiritual enrichment, any attempt to navigate this ocean can also be dangerous and should not be undertaken by those who are not good swimmers. ${ }^{79}$ The use of sea-oriented comparisons to present Islamic mysticism in ways that were intelligible to local audiences is well illustrated in a Malay poem dating from the late fifteenth or early sixteenth century. Composed by the Sufi poet Hamzah Fansuri, it speaks of the gnostic setting sail on perilous waters where 'many ships sink/Its surges are immensely fierce/Its reefs are

76 Lombard-Salmon, 'La communauté chinoise de Makasar', p. 273.

77 Moti Chandra, Trade and trade routes in ancient India (New Delhi: Abhinav, 1977), pp. 61-8, 144-5.

78 Once the Buddha was a monkey: Ārya Śüra's Jätakamālā, foreword by Wendy Doniger, trans. Peter Khoroche (Chicago: University of Chicago Press, 1989), pp. 96-102.

79 Kristin Zahra Sands, Sufi commentaries on the Qur'an in classical Islam (London: Routledge Curzon, 2006), pp. 7, 136-8. 
as sharp as spears/If [the seafarer] is not experienced and skilled enough,/[His] ship will strand and break into pieces' ${ }^{80}$ Muslim texts from Makassar display a familiarity with Sufi ideas circulating in Aceh which also used the image of Allah as the Primeval Ocean. ${ }^{81}$ It may be no coincidence that Makassar voyages to northern Australia, the earliest of which probably dates to the mid-seventeenth century, were undertaken not only in response to increased Chinese demand for trepang, but in the wake of Islam's spread and its promise of far-reaching protection for all believers. ${ }^{82}$

The most venerated and widely dispersed nautical figure was al-Khidir ('the green man'), a mysterious Qur'anic figure who is considered 'one of the most complex legendary figures of the Muslim imaginaire'. ${ }^{83}$ Commonly represented as an old man clothed entirely in green (the Prophet's preferred colour), the hidden significance of al-Khidir's meeting with Moses and his role as the master and possessor of special knowledge intrigued Sufi commentators. More particularly, references to a charmed fish and to boat voyages elevated Nabi (prophet) Khidir as the protector of travellers, especially at sea, and Persian and Indian Muslim artists often depicted him moving across the ocean on a fish. In eastern Bengal he was also venerated by Hindus, who identified him with matsya (lit., 'fish') the first of Vishnu's ten avatars. ${ }^{84}$ For Malays the protection that Nabi Khidir could offer is vividly described in the famed Melaka epic, Hikayat Hang Tuah. During his voyage to India Hang Tuah and his ships encounter a storm, but despite strong winds and waves as high as hills, Allah grants him protection. As a sign of divine favour Hang Tuah meets Nabi al-Khidir, who is seated on a white rock. The saint bestows his blessings on the Melaka hero, presents him with a magic seed, and correctly predicts that the ruler of the Keling land (i.e. India) will ask him to lead a mission to China. ${ }^{85}$ Over time Nabi Khidir's local appeal in Southeast Asia was also strengthened through linkages to indigenous spirits. For an example, there was an implicit connection with Ratu Kidul, also associated with green, and with Puteri Hijau ('Princess Green'), the mysterious underwater spirit who has emerged in the legends of North Sumatra. ${ }^{86}$

The conviction that the baraka, or spiritual power, of eminent Sufi teachers could protect a ship and its crew from danger helps explain the awe with which they were

80 Vladimir Y. Braginsky, 'Some remarks on the structure of the "Sya'ir Perahu" by Hamzah Fansuri', Bijdragen tot de Taal-, Land- en Volkenkunde 131, 4 (1975): 407-26; Vladimir Y. Braginsky, 'The science of women and the jewel: The synthesis of Tantrism and Sufism in a corpus of mystical texts from Aceh', Indonesia and the Malay World 32, 93 (2004): 148-9.

81 The poems of Hamzah Fansuri, Bibliotheca Indonesia 26, ed. and trans. G.W.J. Drewes and L.F. Brakel (Dordrecht: Foris, 1986), p. 83.

82 Paul S.C. Taçon, Sally K. May, Stewart J. Fallon, Meg Travers, Daryl Wesley and Ronald Lamilami, 'A minimum age for early depictions of Southeast Asian praus in the rock art of Arnhem Land, Northern Territory', Australian Archaeology 71 (2010): 1-10.

83 The Qur'an: An encyclopaedia, ed. Oliver Leaman (London: Taylor \& Francis, 2006), p. 34.

84 Ananda K. Coomaraswamy, 'Khwāja Khadir and the fountain of life in the tradition of Persian and Mughal art', in A.K. Coomaraswamy, 'What is civilisation' and other essays (Cambridge: Golgonooza Press, 1989), pp. 157-67; Anna Suvorova, Muslim saints of South Asia: The eleventh to fifteenth centuries (London: RoutledgeCurzon, 2004), p. 167.

85 Hikayat Hang Tuah, ed. Kasim Ahmad (Kuala Lumpur: Dewan Bahasa dan Pustaka, 1971), pp. 342-3. 86 Muhammad Sholikhin, Kanjeng Ratu Kidul dalam perspektif Islam Jawa (Jakarta: Penerbit Narasi, 2009), p. 178; Razali Kasim, Wan Syaifuddin and Olivia Harahap, Kajian perbandingan kisah Puteri Hijau, Melayu Deli (Jakarta: Pusat Bahasa, Departemen Pendidikan Nasional, 2003). 
regarded. Reports of miracles they had performed circulated in all areas frequented by Muslim traders, together with stories of saintly Sufis who walked on the surface of the ocean, leading a ship to safety or miraculously intervening to save a vessel from shipwreck. ${ }^{87}$ Sufi attitudes that promoted the idea of travel in search of religious knowledge melded easily with the economic motivations behind maritime voyages, fostering the extension of Sufi networks into coastal East Africa, India and Java. ${ }^{88}$ In the fourteenth century, for example, the Moroccan Ibn Battuta mentioned the veneration accorded the Sufi leader Abu Ishaq al-Kazaruni (963-1035), who was known to protect sea travellers from storms, shipwreck, pirate attacks or other dangers in return for a pledge of money. 'No ship returns from China or India without yielding many thousands of dinars in votive fees. ${ }^{\prime 9}$ Since baraka could radiate from a saint's tomb, from a personal possession, or even from a place he reputedly visited, there could be multiple sites where assistance could be solicited. Around the Bay of Bengal numerous shrines known as badr-mokan were dedicated to the fifteenth-century Sufi sailor-saint Badr al-Din Awliya, thought to have come from northern India as a wandering preacher, eventually reaching Rakhine on the back of a huge fish. ${ }^{90}$ One mosque with which he was associated (dated to 1756, though probably established much earlier) was located at Akyab, at the entrance to Rakhine's Kaladan River. Because of his links to the coastal areas of Rakhine and Bangladesh, where he meditated and taught, Badr al-Din became the patron of fishermen, boatmen and seafarers more generally. He was so well-known and so popular along the Myanmar coast that nineteenthcentury British observers believed he was a Burmese saint. ${ }^{91}$

As Muslims moved further afield, they took their saints with them, and various shrines honouring Sufi saints dot the coastlines from Bengal to Malaya, testifying to the importance of Muslim maritime trade prior to the nineteenth century. In effect, says Anna Suvorova, these sailor-saints acted as substitutes for al-Khidir; they miraculously moved about in water and in times of peril they appeared give aid to the needy, especially sailors, fishermen and those in danger of drowning. All the rituals of their veneration, she says, are in some way connected with water. ${ }^{92}$ Islam thus provided an umbrella for the movement of locally-revered saints beyond their own locality and for the location of shrines or memories far beyond their birthplace. For instance, offshore islands were often used for restapling or to take on food supplies, especially the drinking water emanating from springs or streams already associated with benevolent spirits. Such places could easily be elevated into Muslim keramat sites through links to travelling saints thought to have visited this spot. In 1786 the young country trader

87 Anne K. Bang, Sufis and scholars of the sea: Family networks in East Africa, 1860-1925 (London: RoutledgeCurzon, 2003), p. 205; Suvorova, Muslim saints, pp. 10-11,

88 Bang, Sufis and scholars of the sea, p. 61.

89 Cited in Ignac Goldziher, Muslim studies, ed. S.M. Stern (Albany: SUNY Press, 1967), vol. 1, p. 284.

90 Suvorova, Muslim saints, pp. 38, 166-7.

91 Sir Richard Temple, 'Buddermokan', Journal of the Burma Research Society 15, 1 (1925): 1-33; Moshe Yegar, The Muslims of Burma: A study of a minority group (Wiesbaden: Otto Harrassowitz, 1972), p. 8; M. Siddiq Khan, 'Badr Maqams or the shrines of Badr Al-Din-Auliya', Journal of the Asiatic Society of Pakistan 2, 1 (1962): 17-46; Richard Forster, 'Magh marauders, Portuguese pirates, white elephants and Persian poets: Arakan and its Bay-of-Bengal connectivities in the early modern era', Explorations 11, 1 (2011): 63-80; Suvorova, Muslim saints, p. 169.

92 Suvorova, Muslim saints, p. 168. 
John Pope mentioned a visit to the small 'Fishers Island' (Pulau Upeh) not far from Melaka, where good water was available (derived, according to legend, from the well on Nakhoda's Ragam's wrecked ship). 'A Mahometan saint is interred here, to whom our Lascars [Indian sailors] paid much respect.' ${ }^{93}$ In the British settlement of Penang, established in 1786, the connections across the Bay of Bengal to the port of Nagore found tangible expression in the dargah (lit., tomb, but here a shrine) built in 1801 and dedicated to the Saint of Nagore, Syed Shahal Hamid. A sixteenth-century Sufi master, he travelled widely to propagate Islam, performed many miracles, and was thought to extend his special protection to seafarers. It is thus not surprising that non-Muslims as well as Muslims came to make offerings. On the day of the festival dedicated to him the shrine was decorated like a ship with pennants fluttering in the breeze, and it was popularly believed that articles thrown into the sea at Penang would be washed up in the saint's own home of Nagore. ${ }^{94}$

Christianity was a late arrival in Southeast Asia, but in the late fifteenth and early sixteenth centuries the Europeans who sailed into the Indian Ocean and then on to China were absolutely convinced of the need for divine assistance. They brought with them a religion in which the sea played a prominent part, from stories of the recruitment of fishermen as disciples to miracles like Christ's calming of a storm. The centrality of Christ's human mother in popular Catholic praxis and her incarnation as Stella Maris, the 'star of the sea' made her a particularly potent symbol of divine protection for ocean voyages. Accordingly, in June 1497, before their epic departure in search of a sea route to India, Vasco da Gama and his crew spent the night in prayer asking that the Virgin Mary would shield them from harm. Missionaries customarily called on heavenly powers to ensure a safe voyage, 'directing frequent prayers to God, to the Virgin most holy, and to all the saints of heaven, invoking the name of every one' ${ }^{95}$ Alexandre de Rhodes, renowned for his evangelisation in Vietnam, recorded that he was saved from a storm at sea by throwing a precious relic, a hair of the Holy Virgin, into the ocean. ${ }^{96}$ Even Chinese traders in Manila, who had become temporary Christians for the purposes of commerce, were grateful for her assistance in ensuring a profitable voyage and a safe return home. According to the Scottish sea captain, Alexander Hamilton (c.1688-1733), 'at their passing by a Mountain dedicated to the Virgin Mary, they throw their Beads over

93 Free mariner, ed. Anne Bulley (Addlestone: British Association of Cemeteries in South Asia, 1992), pp. 89-90. A grave believed to be that of the sixteenth-century Sufi saint, Sultan al-Arifin, is on neighbouring Pulau Besar. Robert Rozehnal, Islamic Sufism unbound: Politics and piety in twenty-first century Pakistan (London: Palgrave Macmillan, 2007), pp. 201-2.

94 A similar dargah in Singapore on Telok Ayer Street, then close to the shore, dates from 1820. Sunil S. Amrith, Crossing the Bay of Bengal: The furies of nature and the fortunes of migrants (Cambridge, MA: Harvard University Press, 2013), pp. 32-7, 89-91; Susan Bayly, Saints, goddesses and kings: Muslims and Christians in South Indian society (Cambridge: Cambridge University Press, 1989), pp. 92-4; GhulamSarwar Yousof, Issues in traditional Malaysian culture (Singapore: Partridge, 2014), pp. 18-21; Khoo Salma Nasution, The Chulia in Penang: Patronage and place-making around the Kapitan Kling Mosque 1786-1957 (Penang: Areca, 2014), pp. 67-70.

95 Ines G. Županov, 'The prophetic and the miraculous in Portuguese Asia: A hagiographical view of colonial culture', in Sinners and saints: The successors of Vasco da Gama, ed. Sanjay Subrahmanyam (Delhi: Oxford University Press, 1998), p. 139; Liam Brockey, Journey to the East: The Jesuit mission to China, 1579-1724 (Cambridge, MA: Belknap Press of Harvard University Press, 2007), pp. 237-8. 96 Rhodes of Vietnam, ed. Solange Hertz (Westminster, MD: Newman, 1966), pp. 66, 100. 
board and thank the Virgin for her Kindness to them'. ${ }^{97}$ A number of stories from Christianised Asia refer to the miraculous appearance of her image on the beach (thus reducing the danger of this liminal zone), often identifying fishermen as the 'discoverers'. The conviction that these life-like images have themselves travelled across the ocean from distant lands is clearly expressed in legendary accounts, like those from the Catholic outpost of Larantuka, in eastern Flores (Indonesia). ${ }^{98}$

In the Southeast Asian context the most striking example of the Virgin as a guardian of sailors is the Philippine Virgin of Antipolo. Brought to Manila from Mexico in 1626, the image gained immediate popularity because it was carved from dark wood and thus resembled a native woman. ${ }^{99}$ During the previous fifty years the annual galleon which crossed the Pacific, bringing Mexican silver from Acapulco to Macao in exchange for silk, had become the primary prop of Manila's economy, but the crossing (which took several months) could be extremely perilous. Thirty of the one hundred and eight ships that traversed the Pacific until the demise of the galleon trade in 1815 sank, with the loss of the valuable cargo and all aboard. Indeed, the ship carrying the Virgin and the new Spanish governor from Acapulco was threatened by a fierce storm, and it was widely believed that only her presence ensured that it arrived safely. On several subsequent occasions captains begged that she would travel to Mexico on the annual galleon, and her reputation as a protector of sea travellers was heightened when ships reached port unscathed. The most notable episode occurred in 1653, when the image of Our Lady was aboard the galleon returning from Acapulco on which the new Governor-General, and several leading clerics, including the Archbishop, were passengers. According to a nineteenth-century account, they were battered by a terrible storm, the rain poured down in torrents, the decks were swept by the surging waves, and it seemed that the ship was doomed. However, 'at [the Virgin's] command the sea lessened its fury, the wind calmed and all the horrors of the voyage ceased'. In gratitude for this protection, the image was granted the title 'Our Lady of Peace and Good Voyage' (Nuestra Señora de la Paz y Buen Viaje); as one passenger put it, 'Our Lady was both pilot and captain'. 100

Belief in divine protection was an intangible but critical factor in maintaining the galleon trade, which also closed the last gap in global maritime connections by linking the South China Sea to the Pacific Ocean. In contrast to the locally grounded rituals of indigenous sea spirits, the previous discussion has shown the extent to which macrocosmic saints moved together with their devotees. This movement is well demonstrated by the Chinese goddess Tian Fei, more commonly known as Mazu, since

97 British Sea-Captain Alexander Hamilton's A New Account of the East Indies, ed. Justin Corfield and Ian Morson (17th-18th century) (Lewiston, NY: Edwin Mellon, 2001), p. 540.

98 Barbara Watson Andaya, 'Christianity, religion and identity in a Muslim environment: Mother Mary, Queen of Larantuka, Indonesia', in Attending to early modern women: Conflict and concord, ed. Karen Nelson (Newark, NJ: University of Delaware Press, 2013), pp. 135-52; Teodora T. Battad et al., Various religious beliefs and practices in the Philippines (Manila: Rex Bookstore, 2008), vol. 1, p. 83.

99 Monina A. Mercado, Antipolo: A shrine to Our Lady (Manila: Craftnotes/Aletheia Foundation, 1980), p. 14. See also Marya Rosenberg Leong, 'The Virgin of the breadfruit tree: The impact of early modern Marian art on Filipino women', in Intercultural exchange in Southeast Asia: History and society in the early modern period, ed. Tara Alberts and D.R.M Irving (London: I.B. Taurus, 2013), pp. 118-43. 100 Mercado, Antipolo, p. 82; John Foreman, The Philippine Islands (London: Sampson Low, Marston, Searle and Rivington, 1890), p. 146. 
the special protection she accorded Zheng He was only one example of a long history of maritime oversight. Attributed with an earthly existence as the daughter of a seagoing family, she first appeared as a coastal deity in Fujian province in the tenth century and apparently incorporated the cult of other female water and river spirits. According to legend she had died young, but was credited with supernatural powers that enabled her to appear as a spirit who would guide ships safely back to shore. ${ }^{101}$ Her reputation spread quickly; in 1122, for example, she was honoured for saving a high official travelling to Korea from shipwreck by descending to the mast of the ship and piloting it to safety. In gratitude, the temple dedicated to her was awarded the title 'Temple of the Fortunate Crossing'. ${ }^{102}$ Under Kublai Khan she was singled out for meritorious service to the state and given the title of Celestial Spouse.

Over the following years Mazu temples proliferated, with popular veneration supported by official endorsements recognising her assistance in maintaining order along the coast. Honours and titles were bestowed upon her, especially under the Qing, whose founder was indebted to her for his own deliverance from a storm. In 1737 she was elevated to Tian Fei, Empress of Heaven, an enhanced status requiring that she should be accorded all the ceremonial regulations that distinguished state cults. ${ }^{103}$ Fishermen and pirates alike regularly worshipped Mazu at her home temple on Meizhou Island, and crews on homeward-bound ships would burn paper money and set off firecrackers as they passed to thank the goddess for their safe and successful return. ${ }^{104}$ By the late eighteenth century nearly every town and village along the South China coast had an Empress of Heaven temple, and the numbers continued to increase. ${ }^{105}$ As Chinese migrants spread through Southeast Asia, Mazu temples were erected in every port and one was even constructed in Kolkata. For overseas Chinese who follow traditional religious beliefs, Mazu veneration still remains an important link to the homeland. ${ }^{106}$

Among ordinary crew members the length of ocean travel, the patterns of shipboard life and the ever-present risk of shipwreck fostered belief in Mazu's maternal vigilance. Similar attitudes hold true for other cultural environments, and it seems that the dangers of shipboard life could encourage greater religious identification. In 1787, fifty sailors from various ethnic groups on an English ship plying the waters between Kolkata and China all professed Islam, but only thirteen had been born to Muslim fathers and three had become Muslim on that very voyage. Seventeen other men called themselves Muslim, and although they were 'not yet made' (presumably had not yet pronounced the syahadat, the confession of faith) they 'complied with all the forms and were admitted to the privilege of eating with [Muslims] and

101 James Watson, 'Standardizing the gods: The promotion of T'ien Hou ('Empress of Heaven') along the South China Coast, 960-1960', in Popular culture in late imperial China, ed. David Johnson, Andrew J. Nathan and Evelyn S. Rawski (Berkeley: University of California Press, 1985), p. 294.

102 Henri Maspero, 'The mythology of modern China', in Joseph Hackin et al., Asiatic Mythology, trans. F.H. Atkinson (New York: Thomas Crowell, 1968), p. 330.

103 Watson, 'Standardizing the gods', pp. 299-300.

104 Antony, Like froth floating on the sea, pp. 157-61.

105 Ibid., p. 155.

106 Zhang Xing and Tansen Sen, 'The Chinese in South Asia', and Tan Chee-Beng, 'Tianhou and the Chinese diaspora', in The Routledge handbook of the Chinese diaspora, ed. Tan Chee-Beng (New York: Routledge, 2014), pp. 206, 417-430. 
were not, for a long time, suspected to be any thing but Mahometans'. ${ }^{107}$ The officially-sponsored Spanish galleons following the route from Manila to Mexico all carried a chaplain to preside over the daily mass, as well as members of the religious orders who prayed over the sick and dying, listened to confessions, and made special supplication for the vessel's safe return. Reports of extraordinary events would have strengthened the sense that the undertaking was in divine hands, as, for instance, in 1648 when a candle flame on the Buen Jesus died of its own accord as a cask of gunpowder was inadvertently approached. Given the dangers that Pacific crossings entailed, it is little wonder that some sailors, arriving safely in Mexico, made the pilgrimage to thank the dark-faced Virgin of Guadalupe, or that in 1603 an existing church in Guadalupe was renamed in her honour. ${ }^{108}$

\section{Oceans, seas, divinities and spirits}

With its many internal seas, Southeast Asia provides a 'throughflow' for tropical waters linking the Indian Ocean and Pacific Oceans. Supported by maritime trade networks, the sea-ocean relationship has been a critical factor in the region's religious history, for the oceans provided a pathway for the introduction of new beliefs that held out considerable appeal to seafarers. In contrast to the sometimes onerous obligations necessary to gain the favour of local spirits or to persuade them to depart without causing a disturbance, the 'macrocosmic' pantheon of teachers, gods, divinities and saints was always willing to listen to the appeals of followers. Unfailingly protective, they were ever ready to guide ships to their destination and forgive lapses of faith - even when sailors neglected to honour vows of penitence offered during a severe storm. ${ }^{109}$ Nor was it difficult to offer devotion, for sea-oriented temples, shrines, churches and other sites were normally located in accessible places along the coast, and were open to devotees of diverse backgrounds. When visiting Surat in 1663, for instance, the Jesuit priest Manuel Godinho remarked that the image of Our Lady of Remedies '[was] worshipped by Christians, Muslims and Hindus alike'. ${ }^{110}$ In the early twentieth century Richard Temple's account of popular attitudes to the Muslim Sufi Badr al-Din Awliya presents a similar picture. 'To the Buddhists he is a nat [spirit]; to the Hindus he is a deva or inferior god; to the Muhammadans, a saint; to the Chinese, a spirit'. ${ }^{111}$ The inherent potency of these items could be further enhanced by their links to distant origins. In Penang the temple dedicated to Mazu, like the Nagore Dargah, was much frequented by sailors, but in 1840 a shrine to the Burmese monk Upagupta - whose mother was a fish and who lived in the middle of

107 Bulley, Free mariner, p. 133.

108 Shirley Fish, The Manila-Acapulco galleons: The treasure ships of the Pacific: With an annotated list of the transpacific galleons 1565-1815 (London: AuthorHouse UK, 2011), pp. 263-4; Rudy P. Guevarra Jr., 'Filipinos in Nueva España: Filipino-Mexican relations, mestizaje, and identity in colonial and contemporary Mexico', Journal of Asian American Studies 14, 3 (2011): 397; Arthur Policarpio, 'The Guadalupe shrine: A tale of destruction, rebirth and war', Totus Tuus, Maria; http://www.all-aboutthe-virgin-mary.com/guadalupe-shrine.html (last accessed 30 Dec. 2016).

109 Borschberg, Memoirs and memorials of Jacques de Coutre, pp. 161-3.

110 Intrepid itinerant: Manuel Godinho and his journey from India to Portugal in 1663, ed. John Correia-Afonso, trans. Vitalio Lobo and John Correia-Afonso (Bombay: Oxford University Press, 1990), p. 32.

111 Some even considered him to have been a shipwrecked Portuguese. Khan, 'Badr Maqams', p. 28. 
the ocean in a gem-studded palace - became another site where seafarers could solicit supernatural assistance. ${ }^{112}$ Further, since universalistic religions were closely allied to economic and political power structures, the benefits of state support could extend to devotees as well. The Chinese case is of particular interest because certain sea divinities were thought to offer worthy service to the state by helping to keep coasts free from pirates. One of the earliest gods to receive imperial favour was probably Hongsheng (Sage Deity, the God of the South Seas), who was officially recognised by the Sui Dynasty in 594 CE. Successive honours awarded by succeeding dynasties culminated in 1725, when the Qing emperor appointed him 'Luminous Brightness Dragon King Spirit of the South Seas'.113

Ultimately, however, the greatest appeal of the 'macrocosmic' deities was their amenability to localisation. As benevolent and all-powerful overlords, they could negate the influence of unfriendly spirits as well as guarantee the goodwill of those that were more well-disposed. In the seventeenth century Spanish missionaries in the Philippines made a concerted effort to replace the ceramic dishes and other items placed on 'rocks, crags, reefs and points along the seashore' as offerings to the spirits with Christian symbols, like crosses and images of saints. Such efforts were only partially successful, since for seagoing peoples the inclusion of Latinised prayers and invocations to God, Christ, Mary and the saints rendered ancient fishing rituals even more powerful than before. ${ }^{114}$

The same holds for Islam, despite the theological opposition to spirit veneration. The ability to appeal to a supremely powerful deity enabled even ordinary fishermen to enter the domain of potentially hostile hantu with confidence. For example, Malays considered the 'great demon' of the tideways, Mambang Tali Harus, to be malevolent, and they approached him circumspectly, sometimes addressing him as 'my friend'. 115 Nonetheless, even he could be reduced to compliance by calling on their Islamic faith and its powers of enforcement. 'Ho, Mambang Tali Harus, see that you do not agitate my hook ... If you approach this hook of mine/you shall be cursed by the sayings of Allah'. ${ }^{116}$

It is over a hundred years since this mantra was collected, but anthropological studies of contemporary seagoing communities show that the amplification of human agency provided by the world religions has continued to infuse 'local

112 Andrew Walker, 'Upakhut in Malaysia', New Mandala, 27 Jan. 2013; http://asiapacific.anu.edu. $\mathrm{au} /$ newmandala/2013/01/27/upakhut-in-malaysia/ (last accessed 1 Sept. 2014); John S. Strong, The legend and cult of Upagupta: Sanskrit Buddhism in North India and Southeast Asia (Princeton: Princeton University Press, 1992), pp. 186-90, 344n2.

113 Benjamin Penny, 'An immigrant Chinese sea god in Australia: The Chinese background to Sydney's Retreat Street temple', Chinese Southern Diaspora Studies 2 (2008): 62.

114 Colin, 'Native races and their customs', in The Philippine Islands, ed. Blair and Robertson, vol. 40, pp. 70-71; Makito Kawada, 'Bayad sa dili naton kaipon: A Visayan ritual of offering to the spirits', in Binisaya nga kinabuhi [Visayan life], ed. Iwao Ushijima and Cynthia Neri Zayas (Quezon City: University of the Philippines, 1996), pp. 213-40.

115 R.J. Wilkinson, Malay beliefs (London: Luzac and Co, 1906), p. 68; W.W. Skeat, 'Some records of Malay magic by an eye-witness', Journal of the Straits Branch of the Royal Asiatic Society 31 (July 1898):

28 . Tideways here refers to a channel in which a tidal current runs.

116 Skeat, Malay magic, pp. 316, 626. A similar threat by a Kelantan fisherman was recorded in Haron Daud, Mantera Melayu: Analisis pemikiran (Penang: USM Press, 2001), pp. 42-3. 'Hei, spirit of the sea ... Do not prevent my good fortune/ If you do this you will be a traitor to Allah.' 
meanings' into the spiritscapes of Southeast Asian seas. In Mandar, for instance, 'Nabi Heder' [al-Khidir] is described as ruler over 'the waves, the wind and the movements of fish from Mandar to Mecca ... He is like the president of the sea', and has even acquired a wife, the restless shoreline spirit, I Sabaria. ${ }^{117}$ The offering of sweet biscuits and cigarettes to a sea spirit may replicate ancient ritual, but it can now be accompanied by the authority of a Muslim imam, who can issue the stern injunction, 'here is your share. Don't you do anything [to me or] my children [or] my grandchildren/Give [them] safe passage if they pass by [here]'. ${ }^{118}$

\section{Conclusion}

The departure point for this article was a re-reading of Ellen Semple's early work on geographic influences on the world's coastal societies, and a registration of her interest in the interaction between seas and oceans. Over the century since her book was published the study of 'maritime history' has expanded and become more sophisticated and more nuanced. This trend is certainly evident in Southeast Asia (which has much to contribute), and anthropologists have provided numerous studies exploring the localisation of incoming religious beliefs among seagoing cultures. However, historical attention to changes in the 'local meanings' that permeate the cosmologies of the maritime world has been more limited. We know that worldwide, all seagoing societies saw boat travel as hazardous and unpredictable, even in familiar waters. In Southeast Asia as elsewhere such attitudes fostered cultures that were highly sympathetic to practices intended to ensure safety and to obtain the goodwill of influential spirits. If prescribed rituals were performed and correct offerings made, the spirits should honour their obligations and ensure a secure and prosperous venture. Yet there was no guarantee of continued goodwill, and spirits could be mischievous and at times malicious. Even when their favour was courted, their reach was limited. As ships moved out into the open ocean, the gods, deities and saints of the world religions could be invoked to lend protection and support in distant and unfamiliar marine environments. Meanwhile, as world religions were incorporated into indigenous cosmologies, maritime peoples gained greater agency in negotiating relationships with the local spirits that still populate Southeast Asian seas. It is this continuing interplay of the human and non-human worlds that makes the study of Southeast Asia's religious life so fascinating and the possibilities of comparative work so intriguing.

117 Zerner, 'Sounding the Makassar Strait', pp. 65, 71-3.

118 Ibid., pp. 66-7. For a detailed account of Muslim interaction with sea spirits in 1939-40, see Firth, 'Faith and scepticism', pp. 190-242. 